\title{
Xanthogranulomatosis of the spleen: a case report
}

\author{
Goshi Fujimoto $^{1 *}$ D, Ken Hayashi ${ }^{1}$, Shigetoshi Yamada ${ }^{1}$, Hiroshi Kusanagi ${ }^{1}$ and Koichi Honma ${ }^{2}$
}

\begin{abstract}
Background: Xanthogranulomatous inflammation is recognized as a subtype of cholecystitis; however, it can also occur in other organs. Xanthogranulomatosis of the kidney, bone, ovary, endometrium, vagina, prostate, lymph nodes and pancreas was reported. Herein, we report a case of laparoscopic splenectomy in a patient with xanthogranulomatosis of the spleen that was difficult to diagnose preoperatively.

Case presentation: A 63-year-old man with a past medical history of hyperlipidemia had gradually growing multiple splenic masses, which were revealed on abdominal ultrasonography. Preoperative imaging suggested hamartoma, extramedullary hematopoiesis, or an inflammatory pseudotumor. Although metastatic splenic tumors and malignant lymphoma are atypical, they were considered in the differential diagnosis. Thus, laparoscopic splenectomy was performed. Pathological results confirmed a diagnosis of splenic xanthogranulomatosis. An increase in the postoperative triglyceride levels indicated that hyperlipidemia was the cause of xanthogranulomatosis of the spleen.
\end{abstract}

Conclusions: Xanthogranulomatosis should be considered in the differential diagnosis of multiple splenic mass lesions in patients with splenomegaly. Additionally, fine-needle aspiration biopsy should be considered for the preoperative diagnosis.

Keywords: Xanthogranulomatosis, Spleen, Hyperlipidemia, Hypertriglyceridemia

\section{Background}

Although xanthogranulomatous inflammation is recognized as a subtype of cholecystitis, xanthogranulomatosis of the kidney, bone, ovary, endometrium, vagina, prostate, lymph nodes, and pancreas was reported [1, 2]. Here, we report a case of laparoscopic splenectomy in a patient with xanthogranulomatosis of the spleen that was difficult to diagnose preoperatively.

\section{Case presentation}

A 63-year-old man with a past medical history of hyperlipidemia had multiple splenic masses, which were revealed on abdominal ultrasonography during a general checkup. His body mass index was $24.9 \mathrm{~kg} / \mathrm{m}^{2}$. Blood tests revealed an elevated triglyceride (TG) level of $963 \mathrm{mg} / \mathrm{dL}$. On the other hand, total cholesterol (TC) level of $112 \mathrm{mg} / \mathrm{dL}$, low-density lipoprotein cholesterol (LDL-C) level of $15 \mathrm{mg} / \mathrm{dL}$, and high-density lipoprotein cholesterol (HDL-C) level of $16 \mathrm{mg} / \mathrm{dL}$ were low. The

\footnotetext{
* Correspondence: g_chimera_7@yahoo.co.jp

${ }^{1}$ Department of Gastroenterological Surgery, Kameda Medical Center,

Kamogawa, Chiba, Japan

Full list of author information is available at the end of the article
}

plasma-soluble interleukin-2 receptor level was normal (Table 1). Bone marrow puncture test was normal. Abdominal ultrasonography (AUS) demonstrated splenomegaly with the spleen measuring $15 \times 8 \mathrm{~cm}$. Splenic echotexture was heterogeneous, and multiple round hyperechoic nodules scattered throughout the spleen were noted (Fig. 1a). Uneven blood flow was observed in the lesion on Doppler imaging (Fig. 1b). Contrast-enhanced computed tomography $(\mathrm{CT})$ in the arterial phase revealed low-density multiple masses (Fig. 2a). Magnetic resonance imaging (MRI) confirmed high signal masses on T2-weighted images (Fig. 2b). A low signal intensity in the early arterial phase and an isointensity in the equilibrium phase of dynamic MRI suggested a solid tumor rather than a cyst (Fig. 2c). On positron emission tomography-CT assessment, the splenomegaly without an abnormal uptake was noted (Fig. 2d). There were no remarkable changes on CT and AUS in the following 10 months. We considered hamartoma, extramedullary hematopoiesis, and inflammatory pseudotumor in the differential diagnosis. Additionally, although metastatic splenic tumors and malignant lymphoma are atypical, they were included in the differential diagnosis. Therefore, 
Table 1 Blood test results of the patient. Blood test results revealed hypertriglyceridemia

\begin{tabular}{llllll}
\hline \multicolumn{5}{l}{ Complete blood count } & \multicolumn{5}{l}{ Serum chemistry } \\
\hline WBC & $5400 / \mu \mathrm{L}$ & TP & $6.7 \mathrm{~g} / \mathrm{dL}$ & $\mathrm{Na}$ & $137 \mathrm{mEq} / \mathrm{L}$ \\
RBC & $443 \times 10^{4} / \mu \mathrm{L}$ & Alb & $4.0 \mathrm{~g} / \mathrm{dL}$ & $\mathrm{K}$ & $4.4 \mathrm{mEq} / \mathrm{L}$ \\
$\mathrm{Hb}$ & $12.6 \mathrm{~g} / \mathrm{dL}$ & T-Bil & $0.6 \mathrm{mg} / \mathrm{dL}$ & $\mathrm{Cl}$ & $102 \mathrm{mEq} / \mathrm{L}$ \\
$\mathrm{Ht}$ & $35.50 \%$ & D-Bil & $0.1 \mathrm{mg} / \mathrm{dL}$ & $\mathrm{Ca}$ & $9.1 \mathrm{mg} / \mathrm{dL}$ \\
$\mathrm{PIt}$ & $11.7 \times 10^{4} / \mu \mathrm{L}$ & $\mathrm{BUN}$ & $18 \mathrm{mg} / \mathrm{dL}$ & $\mathrm{CRP}$ & $0.55 \mathrm{mg} / \mathrm{dL}$ \\
& & $\mathrm{Cr}$ & $0.90 \mathrm{mg} / \mathrm{dL}$ & $\mathrm{TC}$ & $112 \mathrm{mg} / \mathrm{dL}$ \\
Blood coagulation test & LDH & $209 \mathrm{IU} / \mathrm{L}$ & $\mathrm{HDL}-\mathrm{C}$ & $16 \mathrm{mg} / \mathrm{dL}$ \\
PT (INR) & 1.1 & CK & $70 \mathrm{IU} / \mathrm{L}$ & $\mathrm{LDL}-\mathrm{C}$ & $15 \mathrm{mg} / \mathrm{dL}$ \\
PT & $82.80 \%$ & AST & $21 \mathrm{IU} / \mathrm{L}$ & $\mathrm{TG}$ & $963 \mathrm{mg} / \mathrm{dL}$ \\
APTT & $39.6 \mathrm{~s}$ & ALT & $19 \mathrm{IU} / \mathrm{L}$ & $\mathrm{SIL}-2 \mathrm{R}$ & $281 \mathrm{U} / \mathrm{mL}$ \\
\hline
\end{tabular}

WBC white blood cells, $R B C$ red blood cells, $\mathrm{Hb}$ hemoglobin, $\mathrm{Ht}$ hematocrit, $\mathrm{Plt}$ platelet, $P T$ (INR) prothrombin time (international normalized ratio), APTT activated partial thrombin time, $T P$ total protein, $A l b$ albumin, $T$-Bil total bilirubin, $D$-Bil direct bilirubin, $B U N$ blood urea nitrogen, $C r$ creatinine, $L D H$ lactate dehydrogenase, $C K$ creatinine kinase, AST aspartate aminotransferase, ALT alanine aminotransferase, $\mathrm{Na}$ sodium, $\mathrm{K}$ potassium, $\mathrm{Cl}$ chlorine, $\mathrm{Ca}$ calcium $C R P$ C-reactive protein, $T C$ total cholesterol, $H D L-C$ high-density lipoprotein cholesterol, $L D L-C$ low-density lipoprotein cholesterol, $T G$ triglyceride, SIL-2R soluble interleukin-2 receptor

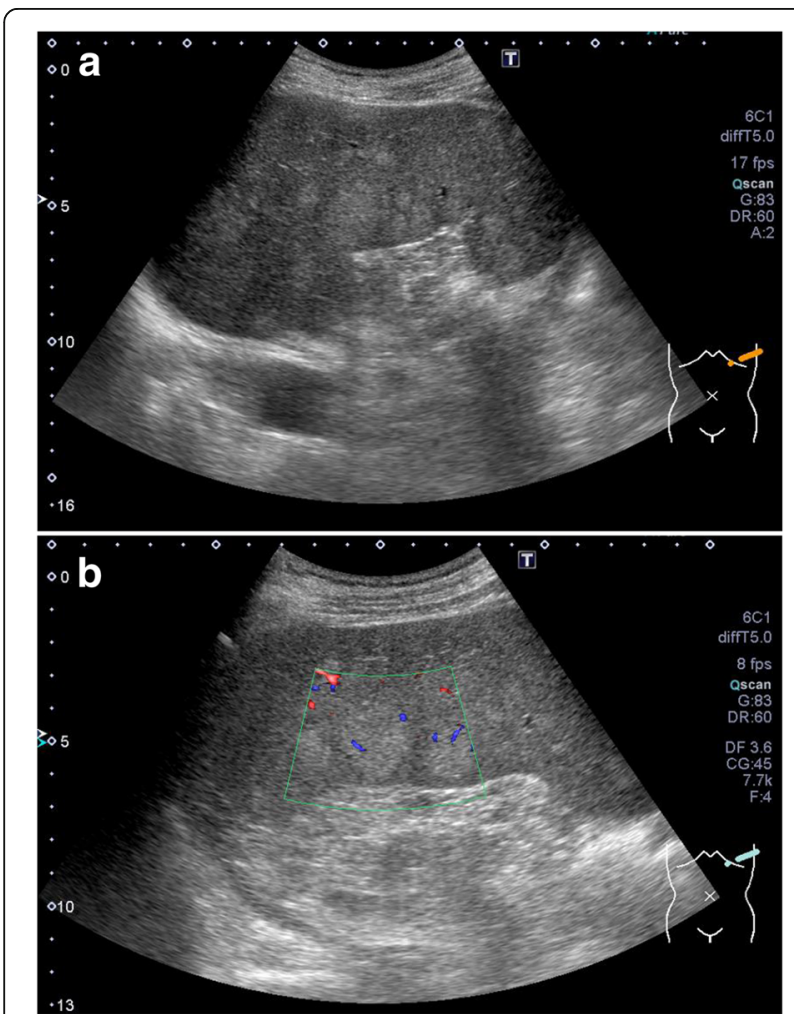

Fig. 1 a Abdominal ultrasonography findings. Multiple round hyperechoic nodules are seen. $\mathbf{b}$ Doppler ultrasonography findings. Uneven blood flow is observed in the lesion laparoscopic splenectomy was performed. We encircled the splenic artery in advance and crumped it during surgery to reduce intraoperative blood loss. In addition, a tape was used to encircle and provide traction around the splenic hilum. The total operating time was $321 \mathrm{~min}$, and the total intraoperative blood loss was $75 \mathrm{~mL}$. Although portal vein thrombosis was noted, it improved with anticoagulant therapy. The patient was discharged on day 17 postoperatively. A resected specimen revealed several elastic soft mass lesions (Fig. 3a). Histological sections revealed an extensive collection of polymorphic foamy macrophages (Fig. 3b), which were not S-100 immunoreactive. Epstein-Barr virus early small RNAs (EBER) were negative. Pathology confirmed a diagnosis of splenic xanthogranulomatosis. The following CT a year and a half after surgery showed no other mass lesions. Despite administration of bezafibrate, the hypertriglyceridemia was difficult to control.

Xanthogranulomatous inflammation is characterized by the clumping of foamy macrophages and infiltration of inflammatory cells $[1,3]$. This lesion is recognized as a subtype of cholecystitis. To our knowledge, this is the first report of a patient with splenic xanthogranulomatosis presenting with multiple masses limited to the spleen. Obstructive conditions and infection can cause xanthogranulomatous changes [1]. Histologically, histiocytosis including Langerhans cell histiocytosis (LCH), hemophagocytic lymphohistiocytosis (HLH), rare Rosai-Dorfmann disease (RDD), Erdheim-Chester disease (ECD), and juvenile xanthogranuloma (JXG) can present with multiple splenic mass lesions. In this case, the cause of xanthogranulomatosis was unclear with respect to the obstructive environment and infection. Macrophages were not S-100 immunoreactive, which suggested that RDD and $\mathrm{LCH}$ were unlikely the causes $[4,5]$. Secondary HLH, which is usually associated with Epstein-Barr virus (EBV) in Asia, was dismissed following negative test results for EBV receptors [6]. ECD and JXG were dismissed based on physical findings [4, 7]. Other conditions that may cause these splenic lesions include extreme hyperlipidemia and a past history of severe bacteremia. Since the latter did not match the history of the present, hypertriglyceridemia was considered. The spleen is essential for the removal of triglyceride-remnant lipoproteins from the plasma. In addition, enhanced macrophage uptake in an intact spleen contributes to a normal plasma lipid concentration. Thus, splenectomy can result in the development of hypertriglyceridemia [8]. In this patient, postoperative TG level was elevated to $4470 \mathrm{mg} / \mathrm{dL}$, which was the highest value for him. Furthermore, four of his six siblings had hypertriglyceridemia. However, the lipoprotein fraction of the patient and his siblings were not previously evaluated. He has not undergone genetic testing. Low LDL$\mathrm{C}$ level ruled out the possibility of familial hypercholesterolemia [9]. Considering his family history, hereditary 

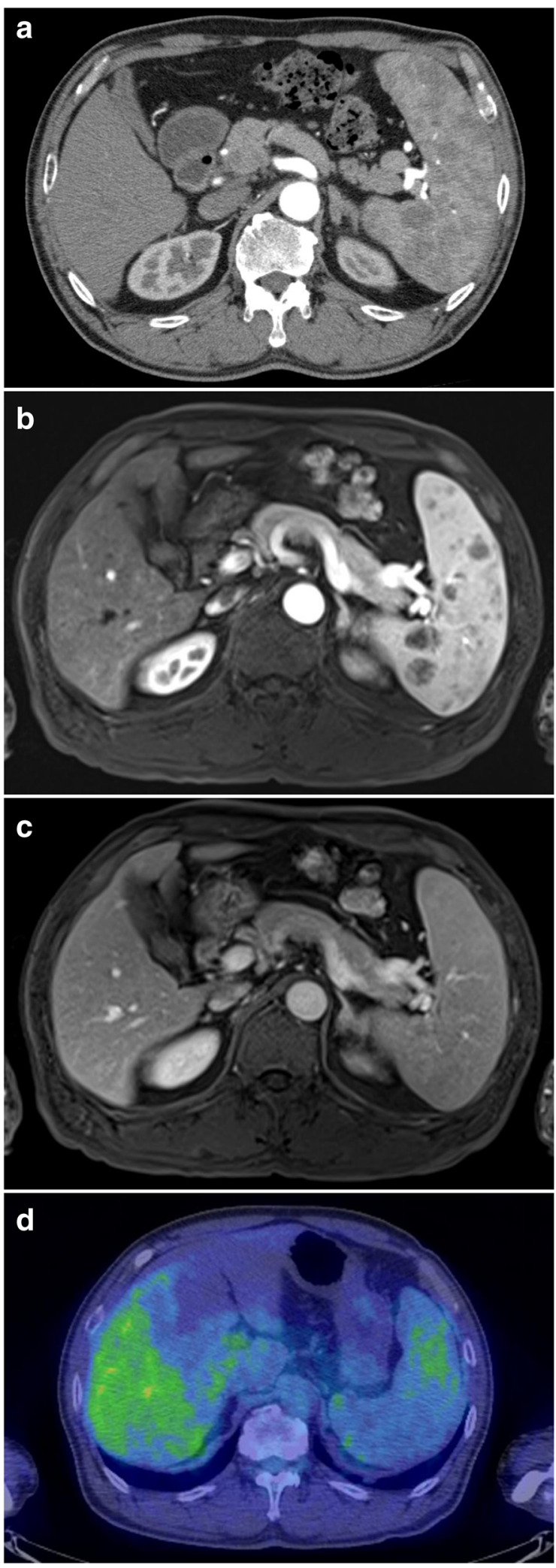

Fig. 2 a Contrast-enhanced computed tomography findings. Multiple mass lesions of low density are noted in the arterial phase. $\mathbf{b}$ Findings of dynamic magnetic resonance imaging in the early arterial phase. The mass lesions show low signal intensities. c Findings of dynamic magnetic resonance imaging in the equilibrium phase. The mass lesions show signal isointensities. d Positron-emission tomography computed tomography findings. Image shows splenomegaly without an abnormal uptake

disorders causing hypertriglyceridemia, such as familial chylomicronemia, familial hypertriglyceridemia, familial combined hyperlipidemia, and familial dysbetalipoproteinemia, are possible [10-14]. Marked hypertriglyceridemia, low level of TC/TG ratio, low LDL-C level, and low HDL$\mathrm{C}$ level of the patient indicate type I or V hyperlipoproteinemia; therefore, familial chylomicronemia and familial hypertriglyceridemia were suspected. It was reported that hyperlipoproteinemia with hypertriglyceridemia and chylomicronemia causes hepatosplenomegaly [15]. However, the mechanism of multiple mass lesions in this case was unclear. To diagnose this mass lesion preoperatively,

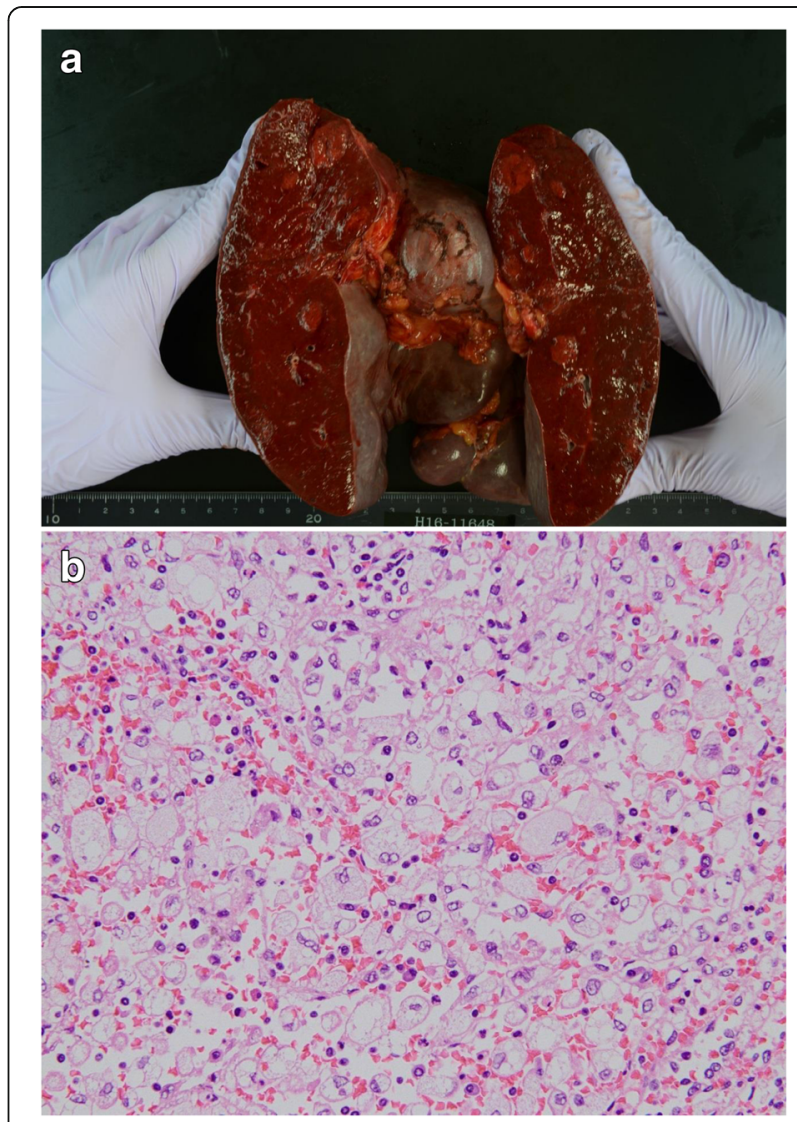

Fig. 3 a Macroscopic findings. A specimen showing splenomegaly (spleen size, $20 \times 14 \mathrm{~cm}$; weight, $940 \mathrm{~g}$ ) with several elastic soft mass lesions. b Microscopic pathology findings. Image shows an extensive collection of polymorphic foamy macrophages 
fine-needle aspiration biopsy may have been necessary to be considered. Although the risk of bleeding after spleen puncture is reported, the biopsy can be performed safely with a fine needle and an appropriate technique. Among 23 patients who underwent splenectomy soon after fineneedle aspiration biopsy, no intrasplenic hematomas or lesions along the needle path were reportedly observed [16]. If xanthogranulomatosis was revealed from the biopsy, splenectomy might have been avoided.

\section{Conclusions}

Xanthogranulomatosis should be considered in the differential diagnosis in patients with splenomegaly. Additionally, fine-needle aspiration biopsy should be considered for the preoperative diagnosis.

\section{Abbreviations}

AUS: Abdominal ultrasonography; CT: Computed tomography; EBER: EpsteinBarr virus early small RNAs; EBV: Epstein-Barr virus; ECD: Erdheim-Chester disease; HDL-C: High-density lipoprotein cholesterol; HLH: Hemophagocytic lymphohistiocytosis; JXG: Juvenile xanthogranuloma; LCH: Langerhans cell histiocytosis; LDL-C: Low-density lipoprotein cholesterol; MRI: Magnetic resonance imaging; RDD: Rosai-Dorfmann disease; TC: Total cholesterol; TG: Triglyceride

\section{Acknowledgements}

We appreciate Editage for editing and proofreading the manuscript for English language.

\section{Authors' contributions}

K.Hayashi, SY, and GF performed the operation. GF and HK wrote the manuscript. K.Honma diagnosed the patient with splenic xanthogranuloma pathologically. All the authors read and approved the final manuscript.

\section{Authors' information}

Three authors are affiliated to the Department of Gastroenterological Surgery, Kameda Medical Center, Kamogawa, Chiba, Japan. GF is a Board Certified Surgeon and Senior Resident, KH and SY are qualified surgeons involved in endoscopic surgical skill qualification system, and HK is the Chief Director. K. Honma is the Vice Director of Anatomic Pathology, Kameda Medical Center, Kamogawa, Chiba, Japan.

\section{Ethics approval and consent to participate}

This case report was approved by Kameda Medical Center, Research Ethics Committee (No. 17-182)

\section{Consent for publication}

Informed consent was obtained from the patient for publication of this case report.

\section{Competing interests}

The authors declare that they have no competing interests.

\section{Publisher's Note}

Springer Nature remains neutral with regard to jurisdictional claims in published maps and institutional affiliations.

\section{Author details}

'Department of Gastroenterological Surgery, Kameda Medical Center, Kamogawa, Chiba, Japan. ${ }^{2}$ Department of Anatomic Pathology, Kameda Medical Center, Kamogawa, Chiba, Japan.
Received: 21 February 2018 Accepted: 11 April 2018

Published online: 19 April 2018

\section{References}

1. Kamitani T, Nishimiya M, Takahashi N, Shida Y, Hasuo K, Koizuka H. Xanthogranulomatous pancreatitis associated with intraductal papillary mucinous tumor. AJR Am J Roentgenol. 2005;185(3):704-7.

2. Addario Chieco P, Antolino L, Giaccaglia V, Centanini F, Cunsolo GV, Sparagna A, et al. Acute abdomen: rare and unusual presentation of right colic xanthogranulomatosis. World J Gastroenterol. 2014;20(26):8717-21.

3. Quatrino GM, Tan MC, Rostas JW, Gunter JW 3rd, Ahmed N, Simmons JD. Xanthogranulomatous cholecystitis. Am Surg. 2015;81(11):E349-50.

4. Haroche J, Cohen-Aubart F, Rollins BJ, Donadieu J, Charlotte F, Idbaih A, Vaglio A, et al. Histiocytoses: emerging neoplasia behind inflammation. Lancet Oncol. 2017;18(2):e113-25.

5. Vassallo R, Ryu JH, Colby TV, Hartman T, Limper AH. Pulmonary Langerhans' cell histiocytosis. N Engl J Med. 2000;342(26):1969-78.

6. Ramos-Casals M, Brito-Zerón P, López-Guillermo A, Khamashta MA, Bosch X. Adult haemophagocytic syndrome. Lancet. 2014;383(9927):1503-16.

7. Pajaziti L, Hapçiu SR, Pajaziti A. Juvenile xanthogranuloma: a case report and review of the literature. BMC Res Notes. 2014;7:W.

8. Rahalkar AR, Wang J, Sirrs S, Dimmick J, Holmes D, Urquhart N, Hegele RA, Mattman A. An unusual case of severe hypertriglyceridemia and splenomegaly. Clin Chem. 2008:54(3):606-10.

9. Bouhairie VE, Goldberg AC. Familial hypercholesterolemia. Cardiol Clin. 2015 33(2):169-79.

10. Benlian P, De Gennes JL, Foubert L, Zhang H, Gagné SE, Hayden M. Premature atherosclerosis in patients with familial chylomicronemia caused by mutations in the lipoprotein lipase gene. N Engl J Med. 1996;335(12): 848-54

11. Ghiselli G, Schaefer EJ, Zech LA, Gregg RE, Brewer HB Jr. Increased prevalence of apolipoprotein E4 in type $V$ hyperlipoproteinemia. J Clin Invest. 1982;70(2):474-7.

12. Veerkamp MJ, de Graaf J, Hendriks JC, Demacker PN, Stalenhoef AF. Nomogram to diagnose familial combined hyperlipidemia on the basis of results of a 5-year follow-up study. Circulation. 2004;109(24):2980-5.

13. Mahley RW, Huang Y, Rall SC Jr. Pathogenesis of type III hyperlipoproteinemia (dysbetalipoproteinemia). Questions, quandaries, and paradoxes. J Lipid Res. 1999:40(11):1933-49.

14. Walden CC, Hegele RA. Apolipoprotein E in hyperlipidemia. Ann Intern Med 1994;120(12):1026-36.

15. Small JM, Moatamed F, Deiss A, Wilson DE. Diabetic lipemia with fatty splenomegaly culminating in unnecessary splenectomy. West J Med. 1987; 147(2):196-8.

16. Solbiati L, Bossi MC, Bellotti E, et al. Focal lesions in the spleen: sonographic patterns and guided biopsy. AJR Am J Roentgenol. 1983;140(1):59-65.

\section{Submit your manuscript to a SpringerOpen ${ }^{\circ}$ journal and benefit from:}

- Convenient online submission

- Rigorous peer review

Open access: articles freely available online

- High visibility within the field

Retaining the copyright to your article

Submit your next manuscript at $>$ springeropen.com 